The Disabled Church 



\section{The Disabled Church}

Human Difference and the Art of Communal Worship

Rebecca F. Spurrier

F O R D H M UN IVERSITY PRESS

New York 2019 


\section{Copyright (C) 2019 Fordham University Press}

All rights reserved. No part of this publication may be reproduced, stored in a retrieval system, or transmitted in any form or by any means-electronic, mechanical, photocopy, recording, or any other-except for brief quotations in printed reviews, without the prior permission of the publisher.

Fordham University Press has no responsibility for the persistence or accuracy of URLs for external or third-party Internet websites referred to in this publication and does not guarantee that any content on such websites is, or will remain, accurate or appropriate.

Fordham University Press also publishes its books in a variety of electronic formats. Some content that appears in print may not be available in electronic books.

Visit us online at www.fordhampress.com.

Library of Congress Cataloging-in-Publication Data

Names: Spurrier, Rebecca F., author.

Title: The disabled church : human difference and the art of communal worship / Rebecca F. Spurrier.

Description: First edition. I New York : Fordham University Press, 2020. I Includes bibliographical references and index.

Identifiers: LCCN 2019028504 I ISBN 9780823285532 (hardback) I ISBN $97808232855^{2} 5$ (paperback) I ISBN 9780823285549 (epub)

Subjects: LCSH: Public worship. I People with disabilities-Religious aspects - Christianity. I People with disabilities-Religious life.

Classification: LCC BVI 5 .S68 2020 I DDC 264.0087-dc23

$\mathrm{LC}$ record available at https://lccn.loc.gov/2019028504

Printed in the United States of America

$$
\begin{array}{llllllll}
2 \text { I } & 20 & \text { I9 } & 5 & 4 & 3 & 2 & \text { I }
\end{array}
$$

First edition 
for Sacred Family Church

and

for Silas 


\section{TEXTUAL DESCRIPTION OF THE \\ COVER ART AND TITLE}

The image on the front cover is a photograph by Cindy M. Brown of a room where Sacred Family artists weave together during weekly day programs. In the center of the photograph is a painting of a loom by a Sacred Family Artist (used here with permission). The loom is rendered in dark green on a bright red background and sits on a black floor. Next to the loom is a small brown table on which are piled cones of thread and a smaller table loom. The painting hangs on a cream-colored brick wall that sits over an actual table on which are piled cones of thread of various sizes and colors - red, gold, green, purple, aqua, white, multicolored. A manual bobbin winder is in the center of the table with scissors beside it.

The dominant colors of red and green in the cover and title are reminiscent of the bright reds and greens of the cover of Nancy L. Eiesland's book The Disabled God, which is referenced by this book's title, The Disabled Church. The title is not a description of Sacred Family Church but rather an argument for the transformation of the Christian church. 